\title{
The effect of alcohol and nicotine abuse on gene expression in the brain
}

\author{
Traute Flatscher-Bader* and Peter A. Wilce \\ School of Molecular and Microbial Sciences, The University of Queensland, Brisbane, QLD 4072, Australia
}

\begin{abstract}
Alcohol intake at levels posing an acute heath risk is common amongst teenagers. Alcohol abuse is the second most common mental disorder worldwide. The incidence of smoking is decreasing in the Western world but increasing in developing countries and is the leading cause of preventable death worldwide. Considering the longstanding history of alcohol and tobacco consumption in human societies, it might be surprising that the molecular mechanisms underlying alcohol and smoking dependence are still incompletely understood. Effective treatments against the risk of relapse are lacking. Drugs of abuse exert their effect manipulating the dopaminergic mesocorticolimbic system. In this brain region, alcohol has many potential targets including membranes and several ion channels, while other drugs, for example nicotine, act via specific receptors or binding proteins. Repeated consumption of drugs of abuse mediates adaptive changes within this region, resulting in addiction. The high incidence of alcohol and nicotine co-abuse complicates analysis of the molecular basis of the disease. Gene expression profiling is a useful approach to explore novel drug targets in the brain. Several groups have utilised this technology to reveal drug-sensitive pathways in the mesocorticolimbic system of animal models and in human subjects. These studies are the focus of the present review.
\end{abstract}

Alcohol abuse: Nicotine abuse: Gene expression: Brain

\section{Gene expression in the mesocorticolimbic system: implications in alcohol and nicotine dependence}

Alcohol is a drug legally consumed in most countries of the world. According to the World Health Organization, alcohol abuse results in $3.2 \%$ of all deaths annually and accounts for $4.0 \%$ of disease burden worldwide ${ }^{(1)}$. A total of $10-18 \%$ of injured patients attending emergency departments are alcohol-related cases $^{(1)}$. In the USA, $8 \%$ of adults fall under the criteria of the Diagnostic and Statistical Manual of Mental Disorders, 4th edition (known as DSM-IV) for alcohol dependence or alcohol abuse ${ }^{(2)}$. Globally, alcohol abuse is the second most common mental disorder ${ }^{(3)}$.

Cognitive defects are a core feature of alcoholism. In recent studies, up to $80 \%$ of alcoholics displayed cognitive deficits in abstract problem solving, spatial and verbal learning, memory formation, perceptual motor skills and problem-solving strategies ${ }^{(4-6)}$. The loss of these cognitive abilities may significantly impair quality of life and affects the treatment process and prognosis ${ }^{(4)}$.

The propensity to abuse alcohol is influenced by both positive (pleasurable effects) and negative (withdrawal, depressed mood states and craving) consequences and overall alcoholism is a complex disease caused by environmental and genetic factors as well as alcoholinduced neuroadaptive changes in distinct brain regions.

Commonality theories of drug abuse propose that dependence on one drug increases the likelihood of dependence on another ${ }^{(7,8)}$. These theories are supported by the many reports of alcoholism and smoking co-morbidity. The incidence of smoking in alcoholics is estimated to be higher than $80 \%^{(9-11)}$. Alcoholics become more dependent on nicotine and have difficulty quitting smoking ${ }^{(12)}$.

Understanding the neurobiological mechanism that contributes to alcohol abuse is critical in developing new pharmacotherapies and treatment strategies. Currently approved pharmaceutical treatments have small to medium effect and none address the persistent increased risk of relapse after drinking cessation. Additionally, the robust co-morbidity of alcohol and tobacco abuse needs to be addressed.

The dopaminergic mesocorticolimbic system (MDS) of the brain is crucially implicated in the development of drug dependence, as this neural circuit mediates motivation processes and appears to be a common target for many,

\footnotetext{
Abbreviations: AMYG, amygdala; BA, Brodmann area; CREB, cAMP response element binding; GABA, $\gamma$-aminobutyric acid; MAPK, mitogen-activated protein kinase; MDS, dopaminergic mesocorticolimbic system; NAC, nucleus accumbens; NPY, neuropeptide Y; PFC, prefrontal cortex; QTL, quantitative trait locus; TIMP, tissue inhibitor of metalloproteinase; VTA, ventral tegmental area.

* Corresponding author: Dr Traute Flatscher-Bader, fax + 6173845 3504, email t.flatscher-bader@uq.edu.au
} 
if not all, drugs of abuse. Dopaminergic neural projections arise in the ventral tegmental area (VTA) in the midbrain and project to several forebrain regions including the nucleus accumbens (NAC) and the prefrontal cortex (PFC). Addictive drugs increase extracellular dopamine preferentially in the NAC either directly or via action on the VTA $^{(13,14)}$. This is significant because the NAC plays a crucial role in learned reward anticipation ${ }^{(15)}$, drug-related learning $^{(16)}$ and craving ${ }^{(17)}$. Repeated abuse results in tolerance to the drug's effects and ultimately results in dependence which is characterised by withdrawal symptoms upon cessation of drug use $\mathrm{e}^{(18-20)}$. Craving may persist for months or years after cessation and is likely to be a consequence of changes in cell structure, function or connectivity induced by long-term drug exposure.

Alcohol's action on the MDS is complex. Alcohol does not bind a specific receptor; instead, it interferes with the activity of a number of proteins including ligand-gated ion channels ${ }^{(2)}$. In animals, acute alcohol enhances $\gamma$-aminobutyric acid (GABA)ergic and inhibits glutamatergic neurotransmission within the $\mathrm{MDS}^{(20)}$. Prolonged drinking has the opposite effect, resulting in region-specific alteration of GABA and glutamate receptor subtype expression $^{(20)}$. Nicotine enhances an excitatory, glutamatergic drive on dopaminergic neurons by binding to specific, pre- and postsynaptic nicotinic acetylcholine receptors in the $\operatorname{VTA}^{(21-23)}$.

The present review focuses on alcohol and nicotine abuse and gives an insight into current approaches that reveal the molecular networks underlying dependence on these drugs. Microarray gene expression profiling simultaneously compares the expression levels of thousands of genes in a tissue. Linear amplification of total RNA allows the use of small amounts of starting material and is a useful tool for exploratory investigation of gene expression in tissue with limited availability. These technologies can provide a snapshot of the transcriptome of specific brain regions relevant to drug addiction. As reviewed below, most work to date has been conducted in animal models. Additionally, several research groups have embarked on elucidating the impact of drugs of abuse on the transcriptome of the human brain. In parallel studies, several groups have characterised the protein changes in selected brain regions of the alcoholic using high-throughput proteomics.

\section{Alcohol-related brain gene expression in animal models}

The heritability of alcoholism is estimated to be as high as 50 to $60 \%{ }^{(24,25)}$. Most diagnostic criteria of alcoholism are behavioural, including failure to control drinking quantity and frequency and continuation with knowledge of the social and medical consequences. It has been argued that there is no rodent model that resembles human alcoholism in all important aspects ${ }^{(26)}$. However, the power of rodent genetics allows a focus on the genetic basis of specific behavioural traits ${ }^{(26)}$. Several rodent strains have been selected for display of particular alcohol-related behaviours and then used to identify candidate genes associated with these behaviours. To identify genetic components, two inbred strains, which differ in the response of interest, are chosen and intercrossed to produce recombinant inbred strains $^{(27)}$. The recombinant strains are then used for quantitative trait locus (QTL) analysis to define chromosomal regions contributing to the phenotype of interest ${ }^{(28)}$. Such a genomic region may harbour a large number of genes and one or several of these may be associated with the selected phenotype. The display of the phenotype could result from the expression of a polymorphism of a target gene(s) and an altered functionality of the gene product. The altered expression pattern of other genes may be a downstream consequence of this changed function.

\section{Genetic predisposition to alcohol preference and to the effects of alcohol}

One approach to identify specific genes and pathways associated with a tolerance of the acute effects of alcohol or preference for alcohol consumption is to compare the baseline gene expression of rodent strains with different phenotypes (Table 1). Bhave et al. investigated the expression levels of gene variants encoding enzymes concerned with alcohol metabolism ${ }^{(29)}$. The expression of alcohol dehydrogenase gene variants was measured in whole-brain extracts of two alcohol-naive mouse strains with different alcohol preference and was shown to be associated with the selected behaviour ${ }^{(29)}$. Tabakoff et al. used mice strains bred for differences in tolerance to acute effects of alcohol and compared whole-brain gene expression between representative individual animals ${ }^{(30)}$. The data were processed using several methods of data filtering followed by statistical analyses. A group of genes, which were concerned with glutamate receptor activity, was revealed. These mapped to previously identified QTL. The candidate genes included those encoding the $N$-methylD-aspartic acid (NMDA) receptor and the glutamate receptor $\delta 2$ protein. Carr et al. aimed to identify genes located within one specific, alcohol-related QTL ${ }^{31)}$. The researchers investigated gene expression in the NAC, PFC, amygdala (AMYG), hippocampus and striatum from congenital rat strains differing only in one alcohol preference-related QTL region on chromosome 4 and exhibiting the selected phenotype ${ }^{(31)} . \delta 2$ Glutamate receptor expression was altered in multiple brain regions, while combined analysis, across all regions, implicated protein phosphatase $\mathrm{C}$ signalling and neuropeptide $\mathrm{Y}$ (NPY) in alcohol preference ${ }^{(31)}$. The involvement of glutamatergic neurotransmission, particularly receptors, in the acute effects of alcohol is well established ${ }^{(20)}$. Protein phosphatase C and NPY signalling contribute to several aspects of alcohol-related behaviour including sensitivity to acute effects of alcohol and control of alcohol consumption ${ }^{(20,32)}$.

In a larger study, the baseline whole-brain gene expression of three selected lines, and six isogenic strains of mice, which again differed markedly in voluntary alcohol consumption, was compared ${ }^{(33)}$. Genes associated with the mitogen-activated protein kinase (MAPK) signalling pathways which regulate activity of cytoskeletal elements and mediate the influence of $\mathrm{NF \kappa B}$ on transcription had predominantly higher expression in alcohol-preferring animals and were proposed to be linked to the alcoholrelated behaviour. Additionally, a group of candidate genes mapped to an alcohol preference QTL on chromosome 9. 
Table 1. Baseline gene expression in rodent strains

\begin{tabular}{|c|c|c|c|c|}
\hline $\begin{array}{l}\text { Molecular pathways } \\
\text { (candidate genes) }\end{array}$ & $\begin{array}{l}\text { Animal } \\
\text { model }\end{array}$ & Strain characteristics & $\begin{array}{l}\text { Brain regions } \\
\text { under study }\end{array}$ & Reference \\
\hline $\begin{array}{l}\text { Alcohol metabolism (alcohol } \\
\text { dehydrogenase gene variants) }\end{array}$ & Mouse & $\begin{array}{l}\text { Strains with different alcohol } \\
\text { preference }\end{array}$ & Whole brain & Bhave et al. (2006) \\
\hline $\begin{array}{l}\text { Glutamatergic transmission } \\
\text { (NMDA receptor, glutamate } \\
\text { receptor } \delta 2 \text { ) }\end{array}$ & Mouse & $\begin{array}{l}\text { Strain with difference in } \\
\text { tolerance to acute effects of } \\
\text { alcohol }\end{array}$ & Whole brain & Tabakoff et al. (2003) \\
\hline $\begin{array}{l}\text { Glutamatergic transmission } \\
\text { (glutamate receptor } \delta 2 \text { ), } \\
\text { phosphatase C and NPY } \\
\text { signalling (NPY) }\end{array}$ & Rat & $\begin{array}{l}\text { Congenital strains, which } \\
\text { differ in one alcohol } \\
\text { preference-related QTL } \\
\text { region on chromosome } 4\end{array}$ & $\begin{array}{l}\text { NAC, PFC, AMYG, } \\
\text { hippocampus, } \\
\text { striatum }\end{array}$ & Car et al. $(2007)^{(31)}$ \\
\hline $\begin{array}{l}\text { MAPK signalling pathways that } \\
\text { regulate activity of cytoskeletal } \\
\text { elements and activity of } \\
\text { transcription factor } \mathrm{NF}_{\kappa} \mathrm{B}(\mathrm{NF} \mathrm{\kappa})\end{array}$ & Mouse & $\begin{array}{l}\text { Three selected lines and six } \\
\text { isogenic strains that differ } \\
\text { in voluntary alcohol } \\
\text { consumption }\end{array}$ & Whole brain & Mulligan et al. (2006) \\
\hline CREB signalling & Mouse & $\begin{array}{l}\text { Inbred Long-Sleep and Short- } \\
\text { Sleep mice, which differ in } \\
\text { expression of genes implicated } \\
\text { in sensitivity ethanol }\end{array}$ & Cerebellum & $\begin{array}{l}\text { Acquaah-Mensah et al. } \\
(2006)^{(35)}\end{array}$ \\
\hline $\begin{array}{l}\text { MAPK and CREB signalling, } \\
\text { pathways associated with } \\
\text { mitochondrial function }\end{array}$ & Rat & $\begin{array}{l}\text { Strains with different alcohol } \\
\text { preference }\end{array}$ & PFC & Sommer et al. $(2006)^{(36)}$ \\
\hline $\begin{array}{l}\text { MAPK signalling in the NAC; } \\
\text { regulation of cell structure in the } \\
\text { AMYG; NPY signalling in the } \\
\text { hippocampus }\end{array}$ & Rat & $\begin{array}{l}\text { Wild-type strains and strains of } \\
\text { different alcohol preference }\end{array}$ & $\begin{array}{l}\text { NAC, hippocampus, } \\
\text { cingulated cortex, } \\
\text { AMYG }\end{array}$ & Arlinde et al. (2004) \\
\hline $\begin{array}{l}\text { MAPK signalling in the ventral } \\
\text { striatum; pathways involved in } \\
\text { learning and memory and with } \\
\text { cell survival in the cerebellum }\end{array}$ & Mouse & $\begin{array}{l}\text { Eight inbred strains with } \\
\text { distinct alcohol-related } \\
\text { behaviour }\end{array}$ & $\begin{array}{l}\text { Ventral striatum, } \\
\text { cerebellum }\end{array}$ & Letwin et al. $(2006)^{(38)}$ \\
\hline
\end{tabular}

Inbred Long-Sleep and Short-Sleep mice differentially express a number of genes thought to be implicated in sensitivity to the effects of ethanol ${ }^{(34)}$. A promoter analysis of genes differentially expressed in the cerebellum in these strains identified cAMP response element binding (CREB) signalling to be a common feature of many of these genes $^{(35)}$. In a study comparing gene expression levels in the PFC of alcohol-preferring and non-preferring rats, MAPK and CREB signalling was again associated with alcoholrelated behaviour ${ }^{(36)}$. Additionally genes concerned with mitochondrial function were differentially expressed between the rat strains ${ }^{(36)}$. NF $\mathrm{BB}$, Jun and CREB signalling as well as mitochondrial function are involved with cell survival and apoptotic events. The signalling pathways and transcription regulatory elements identified by these studies might modulate the detrimental effects of alcohol on the brain.

Arlinde et al. ${ }^{(37)}$ compared gene expression in the NAC, hippocampus, cingulated cortex and AMYG of noncongenital alcohol-preferring, alcohol non-preferring and non-selected Wistar rat strains using Affimetrix arrays containing probes for 1000 genes. Forty-eight genes were found to be differentially expressed between the alcoholpreferring and alcohol non-preferring rat strains. Notably, genes concerned with MAPK signalling were induced in the NAC of alcohol-preferring rats and the levels of a group of transcripts involved with the regulation of cell structure were altered in the AMYG, pointing to region-specific pathways involved in alcohol preference. With the exception of NPY, which was differentially expressed in the hippocampus, none of these genes is located near known QTL for alcohol preference or consumption in rats. This discordance might have been due to the relatively small number of genes analysed. Alternatively, regulatory elements of the genes identified might be located in such QTL. Using eight inbred mice strains with distinct alcoholrelated behaviour, the differential expression of genes involved in MAPK signalling in the ventral striatum was confirmed $^{(38)}$. Further, differentially expressed genes were associated with learning and memory while genes concerned with cell survival again featured in the cerebellum $^{(38)}$. The NAC and AMYG are involved in drug-related learning and craving. The differential expression of genes associated with plasticity within these regions of the MDS may therefore reflect a heightened predisposition for the development of dependence and modulate craving in alcohol-preferring animals.

\section{Effect of alcohol administration on gene expression in the dopaminergic mesocorticolimbic system}

To complement the comparison of baseline gene expression in rodent strains with distinct alcohol-related behaviours, the differences in the effect of alcohol administration on gene expression in several regions of the MDS in these strains have been investigated (Table 2). Kerns et al. exploited the differences in alcohol-related behaviour of C57BL/6 (B6) and DBA/2J (D2) mice: B6 mice drink more alcohol than D2 mice and display a larger locomotor response to acute alcohol exposure ${ }^{(39)}$. Gene expression in 


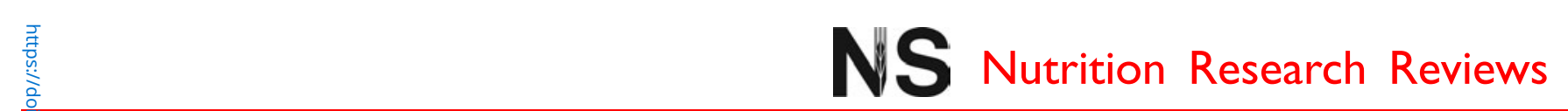

Table 2. Effect of alcohol administration in the animal model

\begin{tabular}{|c|c|c|c|c|c|}
\hline Molecular pathways (candidate genes) & $\begin{array}{l}\text { Animal } \\
\text { model }\end{array}$ & Strain characteristics & Experimental design & Brain region & Reference \\
\hline \multicolumn{6}{|l|}{ 1. Involuntary mode of administration } \\
\hline $\begin{array}{l}\text { Cell differentiation in VTA; growth factor signalling, } \\
\text { developmental pathways and in neurotransmission in } \\
\text { the NAC; glucocorticoid signalling, neurogenesis and } \\
\text { myelination in PFC }\end{array}$ & Mice & $\begin{array}{l}\text { Two strains that differ in } \\
\text { alcohol-related behaviour }\end{array}$ & $\begin{array}{l}\text { Acute intraperitoneal alcohol } \\
\text { injection }\end{array}$ & VTA, NAC, PFC & Kerns et al. (2005) $)^{(39)}$ \\
\hline $\begin{array}{l}\text { Neurotransmission, glutamatergic transmission } \\
\text { (potassium voltage-gated channel, Shab-related } \\
\text { subfamily, member 1; serine/threonine kinase) }\end{array}$ & Mouse & $\begin{array}{l}\text { Thirty BXD recombinant } \\
\text { inbred strains, twenty inbred } \\
\text { strains, two replicate lines } \\
\text { bred for differences in } \\
\text { functional tolerance to } \\
\text { acute alcohol }\end{array}$ & $\begin{array}{l}\text { Testing the co-segregation of } \\
\text { the phenotype of interest } \\
\text { and expected gene } \\
\text { expression level }\end{array}$ & Whole brain & Singh et al. $(2007)^{(40)}$ \\
\hline Transcription factor (Sp1 and $N F_{\kappa} B$ ) signalling & Mouse & One inbred strain & $\begin{array}{l}\text { Acute and chronic alcohol } \\
\text { administration }\end{array}$ & Midbrain & Rulten et al. (2006) $)^{(42)}$ \\
\hline Oxidative stress (oxidoreductases), membrane trafficking & Rat & One inbred strain & Chronic alcohol administration & Hippocampus & Saito et al. $(2002)^{(43)}$ \\
\hline $\begin{array}{l}\text { Insulin-like growth factor } 2 \text { and PI3-kinase signalling in } \\
\text { the AMYG; neurotransmission: cannaboid signalling } \\
\text { (cannaboid receptor CB1), glutamatergic signalling } \\
\text { (EAAT1 and GluR2) in frontal cortex; MAPK } \\
\text { signalling (NFKB) in frontal cortex }\end{array}$ & Rat & One inbred strain & $\begin{array}{l}\text { Chronic alcohol administration } \\
\text { followed by withdrawal }\end{array}$ & $\begin{array}{l}\text { AMYG, } \\
\text { cingulate } \\
\text { frontal cortex }\end{array}$ & $\begin{array}{l}\text { Rimondini et al. } \\
\qquad(2002)^{(44)}\end{array}$ \\
\hline $\begin{array}{l}\text { Protein kinase A signalling and neurotransmission } \\
\text { (GABAergic and glutamatergic transmission) in all } \\
\text { three brain regions; dopaminergic transmission in } \\
\text { medial PFC and NAC }\end{array}$ & Rat & One inbred strain & $\begin{array}{l}\text { Intermittent, chronic alcohol } \\
\text { administration }\end{array}$ & $\begin{array}{l}\text { NAC, medial } \\
\text { PFC, AMYG }\end{array}$ & $\begin{array}{l}\text { Repunte-Canonigo } \\
\text { et al. }(2007)^{(46)}\end{array}$ \\
\hline \multirow{2}{*}{$\begin{array}{l}\text { 2. Self-administration } \\
\text { Neurogenesis }\end{array}$} & & & & & \\
\hline & Rat & One alcohol-preferring strain & $\begin{array}{l}\text { Chronic alcohol self- } \\
\text { administration compared } \\
\text { with natural reward } \\
\text { (saccharine) }\end{array}$ & NAC & Rodd et al. $(2008)^{(48)}$ \\
\hline
\end{tabular}

VTA, ventral tegmental area; NAC, nucleus accumbens; PFC, prefrontal cortex; PI, phosphatidylinositol; AMYG, amygda
4-isoxazolepropionic acid receptor subunit 2; MAPK, mitogen-activated protein kinase; GABA, $\gamma$-aminobutyric acid. 
the VTA, NAC and PFC before and after acute intraperitoneal alcohol injection was compared. Differentially expressed genes were then mapped to previously established alcohol-related QTL in a comprehensive approach to identify genes and signalling pathways associated with the alcohol response. Expression of genes associated with differentiation was altered in the VTA in both strains. Alcohol also affected transcript levels of several growth factors and developmental genes in the NAC, although the response varied in the different strains. In D2 mice, for example, brain-derived neurotrophic factor and genes associated with neurotransmission were altered in the NAC and genes associated with glucocorticoid signalling, neurogenesis and myelination were influenced in the PFC. Hence, a striking theme common to the brain regions investigated in this study was the altered expression of genes associated with plasticity, which suggests neuroplastic alterations within the MDS in the response to acute alcohol administration. Differentially expressed gene sets associated with neuroplasticity and myelination also mapped to chromosomal regions harbouring several ethanol behavioural QTL ${ }^{(39)}$. The studies highlight the importance of neuroplasticity-related pathways within several regions of the MDS which may modulate the susceptibility to excess alcohol consumption.

As emphasised by Singh et al. the cause and effect between differential gene expression and changed phenotypes remain to be established ${ }^{(40)}$. Testing the cosegregation of the phenotype of interest and expected gene expression level in independent genetic crosses or using recombinant inbred mice strains could strengthen this link ${ }^{(40)}$. Towards this aim, Hu et al. utilised thirty BXD recombinant inbred strains of mice, twenty inbred strains of mice, and two replicate lines of mice selectively bred for differences in functional tolerance to acute alcohol to compare baseline gene expression ${ }^{(41)}$. Differentially expressed genes were mapped to known QTL. The level of selected gene expression was correlated to the phenotype and the heritability was monitored. Eight genes were identified as candidate genes for acute alcohol tolerance. They included K voltage-gated channel, Shab-related subfamily, member 1, which dampens excitability of neurons and serine/threonine kinase, which can influence glutamatergic transmission. In combination with previous studies $^{(30,31,38,39)}$, the results again strongly imply neuron excitability and particularly glutamatergic transmission as a target for acute alcohol. The identification of similar genes and signalling pathways associated with alcohol-related behaviours in various rodent models highlights the benefits of combining gene expression studies with genetics to reveal gene networks in the brain that may be involved in a predisposition to alcohol abuse and addiction.

Inbred rodent strains of identical genetic background were utilised to establish the impact of alcohol administration on brain gene expression. The aim of these studies was to mimic neuroadaptations associated with alcohol tolerance and dependence. Rulten et al. investigated the impact of acute alcohol on midbrain gene expression in mice, $2 \mathrm{~h}$ following a single intraperitoneal ethanol dose ${ }^{(42)}$. Genes concerned with transcription factor $\mathrm{Sp} 1$ and $\mathrm{NF} \mathrm{B}$ signalling pathways were found differentially expressed.
Sp1 and NFкBi $\alpha$ expression were also altered in mice fed an escalating ethanol diet for 3 weeks $^{(42)}$, implicating these pathways in acute as well as chronic alcohol responses.

Wistar rats offered a $12 \%$ alcohol solution as the only source of liquid for 12 weeks were used to elucidate the effect of chronic alcohol exposure on gene expression in the hippocampus $^{(43)}$. The expression of sets of genes encoding oxidoreductases and proteins concerned with membrane trafficking was altered. This may reflect oxidative stress and an interference with membrane function. Rimondini et al. investigated the impact of 7 weeks of repeated cycles of alcohol vapour treatment and withdrawal on gene expression in the AMYG and the cingulate frontal cortex of Wistar rats ${ }^{(44)}$. This treatment paradigm induces increased voluntary alcohol consumption. In the AMYG, transcript levels of insulin-like growth factor 2 and genes involved in phosphatidylinositol 3-kinase signalling were affected. The role of these genes in responses to alcohol dependence within the AMYG is unknown. Expression of genes associated with MAPK signalling was altered in the PFC. Once more, induction of $\mathrm{NF \kappa B}$ confirms adverse effects of alcohol on this brain region. Elevated levels of genes concerned with neurotransmission were revealed in the cortex and included the cannaboid receptor CB1. Accordingly, administration of cannaboid receptor antagonist SR141716A reduces alcohol consumption in strains of alcohol-preferring rats, presenting a pharmaceutical target for the treatment of alcoholism ${ }^{45)}$. The induction of the excitatory glutamate transporter 1 (known as EAAT1 or GLAST) and glutamatergic $\alpha$-amino-3-hydroxy-5-methyl4-isoxazolepropionic acid (AMPA) receptor subunit 2 observed in this study ${ }^{(4)}$ may represent an adaptation to altered glutamatergic transmission. Repunte-Canonigo et al. utilised the same treatment and animal model to investigate the impact of intermittent alcohol administration on the transcriptome of the NAC, medial PFC and AMYG ${ }^{(46)}$. An observed alteration in expression of genes regulating protein kinase A signalling in all three brain regions could have a downstream modulatory effect on CREB signalling. A number of dopamine-regulated transcripts were differentially expressed in the medial PFC and NAC, which might indicate an alteration in dopaminergic drive. Together with a region-specific change in expression of GABA and AMPA receptor subunits, these results suggest extensive but specific adaptive alteration to neurotransmission in response to chronic alcohol administration.

\section{Effect of alcohol self-administration on gene expression in the dopaminergic mesocorticolimbic system}

Such involuntary treatment regimens might induce severe stress responses and as such not fully reflect voluntary and intermittent excessive drinking in human alcoholics. Saito et al. minimised these variables by utilising two mice strains with different alcohol preference. The researchers applied a $9 \mathrm{~d}$ voluntary self-administration model with an escalating regimen of alcohol concentration ${ }^{(47)}$. This treatment regimen failed to produce significant changes to gene expression and may have been too mild to produce dependence. Rodd et al. investigated the impact of operant ethanol self-administration on gene expression in 
NAC inbred alcohol-preferring rats by comparing differences and commonalities between the effect of a natural reward and alcohol ${ }^{(48)}$ (Table 2). The expression of genes encoding proteins associated with the synapse and homeostasis was altered in response to ethanol or saccharin. Genes associated with neurogenesis were differentially expressed between ethanol and the natural reward administration. These genes may therefore be sensitive to the specific incentive.

\section{Sex-specific action of alcohol}

Male rodents are mainly utilised for gene-expression studies investigating the effect of alcohol exposure. However, the effect of sex was revealed in a recent study on gene expression in male and female rodent brains after $72 \mathrm{~h}$ exposure to ethanol vapours followed by $8 \mathrm{~h}$ withdrawal ${ }^{(49)}$. The study highlights significant sex-specific differences. In the female the treatment regimen had an impact on expression levels of genes involved in cell death, while altered expression of genes concerned with protein modification and degradation featured in male brains. Histopathological analysis of brain damage confirmed that the observed cell death was sex specific.

\section{Nicotine-responsive gene expression in the animal model \\ Effects of nicotine administration on gene expression in the dopaminergic mesocorticolimbic system}

To a lesser extent than alcohol, the effect of acute and chronic nicotine on gene expression in the brain has also been investigated in rodents (Table 3). In mice, acute nicotine altered the expression of genes associated with plasticity in the $\mathrm{VTA}^{(50)}$. Ras homologue gene family, member A, a gene involved in structural remodelling, was then selected from this gene set for a case-control gene association study in human subjects and found to be significantly associated with smoking initiation ${ }^{(50)}$. Intermittent nicotine administration followed by withdrawal elicited significant locomotor sensitisation in quasi-congenic RQI and donor BALB/cJ mice but not in C57BL/6ByJ mice. Gene expression was monitored in the VTA of these strains ${ }^{(51)}$. Nicotine-responsive genes were concerned with signal transduction, intracellular protein transport, proteasomal ubiquitin-dependent protein catabolism, and neuropeptide signalling. While some nicotine-responsive genes and pathways overlapped, there were distinct differences between the strains. This suggests common regulatory mechanisms across inbred strains but also, that a small difference in genetic constitution significantly affects transcriptome response to nicotine.

An earlier microarray study established that repeated nicotine treatment affects several signal transduction pathways in the PFC, NAC, VTA and $\mathrm{AMYG}^{(52)}$ of Holtzman rats. In the PFC, VTA and AMYG, genes involved in MAPK signalling were revealed as nicotine sensitive. mRNA levels of genes involved in phosphatidylinositol signal transduction were affected in the NAC, VTA and AMYG in a region-specific manner. Transcript levels of genes associated with the epidermal growth

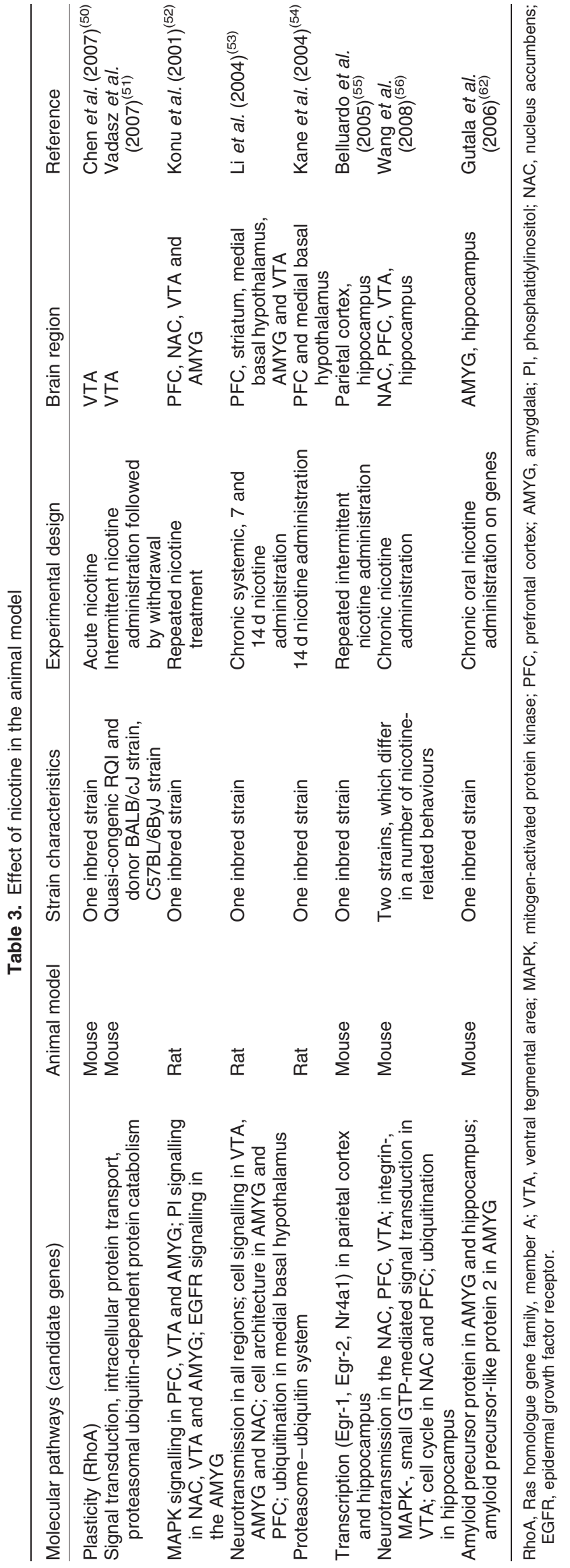


factor receptor (EGFR) signalling pathway were altered in the AMYG. In a follow-up study using pathway-focused arrays these signalling cascades were investigated further in the PFC, striatum, medial basal hypothalamus, AMYG and VTA of the rat brain in response to subacute and chronic systemic nicotine administration ${ }^{(53)}$. Rats were killed at 3,7 and $14 \mathrm{~d}$ of nicotine administration. The observed changes in gene expression were highly regionspecific and dynamic over the time studied. Thus, genes involved in signalling events were up-regulated at day 3 in the AMYG and at day 7 in the NAC and down-regulated over time in the VTA. These changes may be an adaptive process to chronic nicotine treatment. The expression of genes associated with the cytoskeleton was reduced after $14 \mathrm{~d}$ in the AMYG. Such genes were altered in the opposite direction in the PFC, which may indicate regionspecific restructuring events in response to chronic nicotine. Genes concerned with inhibitory GABAergic neurotransmission were down-regulated while those concerned with glutamatergic transmission were induced, indicating an increased excitatory drive in response to systemic nicotine administration. In the medial basal hypothalamus a reduction of transcripts associated with ubiquitination was evident over time. These alterations were further explored in the PFC and medial basal hypothalamus in a third study by the same research group, again utilising customised pathway-focused microarrays ${ }^{(54)}$. The $14 \mathrm{~d}$ nicotine administration applied in this study modulated expression of genes associated with the proteasome-ubiquitin system in a region-specific manner. The authors hypothesise that the observed changes may be caused by oxidative stress or changes to synaptic activity. Together with previous findings ${ }^{(51)}$ this strongly suggests that nicotine has distinct effects on cellular protein homeostasis within the MDS.

Another research group investigated gene expression in response to repeated intermittent nicotine administration on the parietal cortex of mice and identified altered expression of a set of transcription factors ${ }^{(55)}$. Subsequently they utilised in situ hybridisation to confirm elevated levels of the immediate early genes, Egr-1 and Egr-2, as well as the orphan nuclear receptor, Nr4a1, in the parietal cortex and the hippocampus. The transcription factor activities of the protein products of these nicotine-sensitive genes could induce expression of a large number of other genes in a secondary response.

\section{Effect of genetic predisposition on expression of nicotine-sensitive genes in the dopaminergic mesocorticolimbic system}

Recently, a comprehensive study investigated genetic predisposition and the effect of chronic nicotine gene expression in five regions within the MDS in two mice strains $^{(56)}$. $\mathrm{C} 3 \mathrm{H} / \mathrm{HeJ}$ and $\mathrm{C} 57 \mathrm{BL} / 6 \mathrm{~J}$ mice differ in a number of nicotine-related behaviours. $\mathrm{C} 3 \mathrm{H} / \mathrm{HeJ}$ mice self-administer less nicotine ${ }^{(57)}$ and a low dose of nicotine increases locomotor activity in $\mathrm{C} 3 \mathrm{H} / \mathrm{HeJ}$ mice but depresses it in C57BL/6J mice ${ }^{(58)}$. $\mathrm{C} 3 \mathrm{H} / \mathrm{HeJ}$ mice develop tolerance only at higher doses of chronically infused nicotine $^{(59)}$. A pathway-focused microarray and gene ontology analysis were used to compare the impact of chronic nicotine administration on gene expression in the NAC, PFC, VTA, AMYG and hippocampus. In both strains nicotine had an impact on genes concerned with neurotransmission in the NAC, PFC and VTA. The expression of some of these genes was affected in inverse directions and included the nicotinic acetylcholine receptor $\alpha 4$ subunit. Genes concerned with glutamatergic transmission were altered in the NAC and PFC in a strainspecific manner. These changes were consistent with differences in sensitivity to nicotine and nicotine-related behaviours in the two strains. In $\mathrm{C} 3 \mathrm{H} / \mathrm{HeJ}$ mice, nicotine induced expression of genes concerned with integrin-, MAPK- and small guanosine triphosphatase-mediated signal transduction in the VTA, which points to structural alterations in response to chronic nicotine within this core region of the MDS. Genes associated with the cell cycle were induced in the NAC and down-regulated in the $\mathrm{PFC}$ in response to chronic nicotine in $\mathrm{C} 3 \mathrm{H} / \mathrm{HeJ}$ mice. Products of these genes may have a role in synaptic plasticity. Genes concerned with protein ubiquitination and catabolism were again affected in the hippocampus in C57BL/6J mice.

\section{Protective effects of nicotine}

Epidemiological and molecular studies have indicated that nicotine may have neuroprotective potential against Alzheimer's and Parkinson's diseases ${ }^{(60,61)}$. To investigate this further, the effect of chronic oral nicotine administration on genes encoding amyloid $\beta$ and related proteins was studied in brain regions of mice using a pathway-specific microarray ${ }^{(62)}$. The evident up-regulation of genes for amyloid precursor protein in the AMYG and hippocampus and amyloid precursor-like protein 2 in the AMYG may contribute to the protective effects of nicotine against Alzheimer's disease.

\section{Common molecular targets of alcohol and nicotine within the dopaminergic mesocorticolimbic system}

Nicotine interacts with specific nicotinic acetylcholine receptors in the first instance. However, these studies highlight that a number of molecular pathways are implicated in the events following acute and chronic nicotine exposure. Importantly, when comparing the effects of alcohol and nicotine in the animal model, an overlap in affected signalling pathways, particularly the MAPK and phosphatidylinositol signalling cascades, is evident. Additionally, one may ponder if rodents and the applied treatment regimens fully model human alcohol and/or nicotine abuse and addiction. An important caveat in the animal model is the difficulty in reflecting changes occurring in the human MDS over a lifetime of abuse and relapse.

\section{Gene expression profiling of the human prefrontal cortex of chronic alcoholics}

Changes to gene expression and molecular pathways within the MDS associated with long-term alcoholism have been 
identified by investigating human post-mortem brain tissue of chronic alcoholic and control cases ${ }^{(63-69)}$. The PFC (particularly Brodmann area 9; BA 9) is involved in working memory and is connected to the hippocampus, association areas and parietal cortex, thus providing information on the context of stimuli for higher-order sensory processing. Alcohol abuse has an adverse impact on this brain region. Older alcoholics exhibit a decrease in white matter volume $^{(70)}$ and a significant neuronal loss in grey matter $^{(71,72)}$. The PFC was the first brain region in human subjects to be investigated by gene expression profiling by two research groups ${ }^{(63-67,69)}$.

In early microarray studies on the PFC of the chronic alcoholic, restrictions in human brain tissue resources required pooling of mRNA samples. These studies revealed changes to the expression of several hundred genes in the chronic alcoholic ${ }^{(65,66)}$, including genes concerned with myelination. Advances in technology later enabled investigators to profile the transcriptome of the PFC in individual samples ${ }^{(64,67,69)}$. These studies also identified an alteration in the expression of genes concerned with myelination, which may point to an interference of alcohol with membrane integrity and neurotransmission. Further, in two studies the expression of transcription factors, including the immediate early genes, activator protein 1 (AP-1) and CREB, was sensitive to chronic alcohol abuse ${ }^{(64,69)}$. These results are in accordance with expression profiling in the animal models ${ }^{(36)}$ and may indicate an alteration to cell fate in the PFC of the long-term alcoholic. Certainly, loss of neurons is a characteristic of the PFC of the alcoholic $^{(70)}$.

The detrimental effects of alcohol on the brain may be an effect of the direct toxicity of alcohol and its first metabolite acetaldehyde. In addition, changes in the balance of inhibitory and excitatory neurotransmission in the cortex may elevate neuronal sensitivity to glutamate during withdrawal to levels causing excitotoxicity ${ }^{(73-75)}$. Interestingly and similar to the animal model ${ }^{(44)}$, one study revealed a robust induction of the glial glutamate transporter, excitatory amino acid transporter 1 , in the PFC of the human alcoholic $^{(76)}$. Consequently, the altered expression of this transporter was confirmed at the protein level ${ }^{(77)}$. Taken together these studies point to a protective role of excitatory amino acid transporter 1 against the potentially cytotoxic glutamate level following withdrawal ${ }^{(75)}$. Chronic ethanol treatment of rats results in DNA damage and an increased level of heat shock proteins in the cortex ${ }^{(78,79)}$. Correspondingly, in the PFC of the human alcoholic, genes associated with DNA repair and those encoding a number of heat shock proteins and free radical scavengers were induced ${ }^{64,65,69)}$. The down-regulation of mitochondrial genes including those associated with electron transport or energy production was revealed in two studies ${ }^{(64,67)}$. Mitochondrial function was again implicated in the animal model of alcohol preference ${ }^{(36)}$. These changes indicate that disruption of mitochondrial function may be a possible source of oxidative stress. In summary, microarray gene expression studies on the PFC of human alcoholics identified gene groups associated with a disturbance of membrane function, transcription and oxidative stress and cell death and survival. The alteration in transcription observed in these genes may reflect the neuronal cell loss evident in the longterm alcoholic ${ }^{(71,72)}$

Comparisons of the various studies on the human PFC reveal few common specific alcohol-sensitive genes and only partial overlap in functional gene groups. The inconsistency between the studies emphasises the need for strictly controlled experimental set ups. As reviewed previously, uncharacterised cases as well as experimental factors may play a role in the divergent results ${ }^{(80)}$. Possible confounding factors in human studies include mode of death, tissue $\mathrm{pH}$, white matter contamination, post-mortem interval, onset of drinking, age, intoxication state at death, co-morbidity with other drugs of abuse or with underlying psychiatric disorders. Distinct differences in experimental design, application of various microarray platforms together with platform-specific methods to treat and hybridise input RNA sample and the choice of method of analysis may lead to pronounced differences in the results. Despite these caveats, the studies have revealed alcohol-sensitive gene groups highly relevant to the pathology evident in the PFC of the chronic alcoholic. The accordance of genes and gene networks with those identified in expression profiling using rodent models highlights that the two approaches are complementary in the identification of alcohol-responsive molecular pathways.

\section{Comparative gene expression profiling of regions of the dopaminergic mesocorticolimbic system in chronic alcoholics}

In a series of microarray studies our research group profiled the PFC (BA 9), NAC and VTA of long-term alcohol abusers ${ }^{(63,64)}$ using a consistent method of RNA extraction, linear amplification, microarray platform, hybridization, as well as data analysis. In the studies of the $\mathrm{BA} 9$ region of the $\mathrm{PFC}$ and the NAC a two-colour design was used ${ }^{(64)}$, while for expression screening of the VTA a universal reference was applied ${ }^{(63)}$. The results of each microarray study were verified by real-time PCR on selected genes.

Comparing differentially expressed genes between the three studies, the highly region-specific action of alcohol was a striking observation ${ }^{(80)}$. No alcohol-sensitive gene was common between the three studies and only $4 \%$ between any two. Functional clusters of alcohol-sensitive genes identified in the NAC and VTA were clearly distinct from the PFC. With the exception of a group of genes concerned with transcription in the VTA, none of the main themes present in the PFC was observed in the VTA or NAC. The most pronounced functional group in the VTA contained genes associated with cell signalling. In the VTA and the NAC a number of genes were associated with synaptic and/or structural plasticity.

In early microarray studies, genes associated with alcohol abuse were grouped manually into functional groups $^{(64-66)}$. More recently, functional data mining of large microarray datasets using independent softwares has been applied as an unbiased tool to reveal the biology underlying a dataset ${ }^{(63,67)}$. The web-based software Database for Annotation Visualisation and Integrated 
Analysis (DAVID/EASE; National Cancer Institute at Frederick, Frederick, MA, USA; http://david.abcc.ncifcrf. gov/) groups genes into specific categories considering their multi-functionality ${ }^{(81-83)}$. Further, the software identifies over-represented annotation terms and biological themes using $\kappa$ statistics and maps genes to canonical Kyoto Encyclopedia of Genes and Genomes pathways ${ }^{(82)}$. DAVID/EASE analysis (National Cancer Institute at Frederick) on the datasets of differentially expressed genes was performed for the VTA, PFC (Table 4) and the NAC (Table 5) to reveal over-represented annotations and functional gene groups within the three brain regions. Groups of genes associated with transcription or apoptosis were enriched in the PFC only. Over-representation of genes coding for proteins involved with modification of the extracellular cellular matrix was unique to the NAC. For example, tissue inhibitor of metalloproteinase (TIMP) 1 and TIMP4 were induced, while TIMP2 was downregulated. This suggests an alteration to extracellular matrix homeostasis. Additionally, genes concerned with cell adhesion featured in a separate cluster. They included integrin, $\alpha 6$, T-cell lymphoma invasion and metastasis 1 , contactin-associated protein-like 2 and ninjurin 2. Genes associated with tissue development, neuronal cell morphology and neuron morphogenesis and differentiation were also tied into multiple independent clusters. These functional themes strongly suggest structural plasticity in the NAC of the chronic alcoholic. To a lesser extent, genes which are expressed during structural plasticity were also identified as enriched in one functional cluster in the VTA $^{(63)}$. Of interest within these functional clusters were molecular targets common to both the NAC and VTA. In both regions, chronic alcohol abuse changed the expression of genes participating in integrin-mediated alteration of the cytoskeleton. Enduring, structural plasticity within the NAC and VTA in response to repeated drug administration has been observed in animal models ${ }^{(84)}$. These changes are thought to underlie the persistence of craving and relapse. Interestingly, comparing studies on human and animal models, a meta-analysis identified genes concerned with structural plasticity to feature in the group of top candidate genes for alcoholism ${ }^{(85)}$. Further, in the human VTA, genes concerned with neurotransmitter transport and release were significantly over-represented amid the alcohol-sensitive genes identified ${ }^{(63)}$. In conclusion, comparative expression profiling of distinct regions of the human MDS revealed a region-specific impact of alcohol. Structural plasticity in the NAC and VTA may underlie enduring alterations to connectivity within these two brain regions and open up novel avenues for drug research.

\section{Tobacco co-abuse in chronic alcoholics}

There is a strikingly high coincidence between alcoholism and smoking. Alcoholism is more prevalent in smokers than non-smokers and 80-90\% of alcoholics are heavy smokers compared with $33 \%$ of the global population ${ }^{(11)}$. Smoking cessation is more difficult in former and current alcoholics and cessation of smoking improves the chances of a reduction in alcohol consumption ${ }^{(12)}$. In addition, smoking may act as a precipitant of relapse to alcoholism ${ }^{(12)}$. In comorbid cases, drinking elevated craving for cigarettes and smoking cues increased the desire for alcohol ${ }^{(86)}$. Recent meta-analysis of linkage and association studies have identified candidate genes which may predispose an individual to addiction to more than one $\operatorname{drug}^{(87)}$. These included genes involved in dopamine and serotonin neurotransmission and in drug metabolism. Potential predisposition to alcohol and nicotine dependence predominated ${ }^{(87)}$. Despite the potential for extensive interactions, most studies on gene expression within the MDS of the human alcoholics using high-throughput genomics have not taken account of the common co-morbidity of smoking and alcoholism ${ }^{(64-69)}$. Compelling evidence arising from two recent studies identified that smoking has a profound impact on alcohol-related gene expression in the human. In the PFC and VTA, the expression levels of selected alcoholsensitive genes were established in an extended case set of alcoholics with or without smoking co-morbidity, non-alcoholic smokers and non-smoking, non-drinking controls ${ }^{(63,76)}$. In the PFC, smoking alone altered expression of apolipoprotein D (APOD) and midkine and increased variance in the expression of TIMP3 and excitatory amino acid transporter $1^{(76)}$. The neurotrophic factor, midkine, is induced after ischaemia ${ }^{(88)}$. TIMP3 facilitates doxorubicin-induced apoptosis in neuronal culture ${ }^{(89)}$. APOD function is yet unknown, but the expression of this gene was altered in schizophrenics and patients with bipolar disorder ${ }^{(90)}$. Smoking is associated with impairment of cognitive functions ${ }^{(91)}$ and exacerbates alcohol-induced neuronal injury ${ }^{(92)}$. Taken together, these studies emphasise that smoking alone may have a negative effect on cell viability in the PFC.

In the VTA, smoking and alcohol interacted to alter the expression of excitatory amino acid transporter 2 and smoking alone induced expression of vesicular glutamate transporters 1 and $2^{(63)}$. These changes indicate a potentiation of glutamatergic neurotransmission in response to smoking $^{(93)}$. Glutamatergic transmission is vital for the control of the VTA and may also be critical to the weighting of novelty and importance of a stimulus, an essential output

Table 4. Functional enrichment clustering of genes associated with alcohol abuse in the human prefrontal cortex (PFC) ${ }^{\star}$

\begin{tabular}{llllr}
\hline Functional group & $n$ & Category & Annotation term & $n$ \\
\hline Cell fate & 26 & GOTERM_BP_ALL & Induction of apoptosis & 5 \\
Transcription & 50 & INTERPRO_C_ALL & Zn finger, C2H2-type/integrase, DNA-binding & 6 \\
Gene product location & 33 & GOTERM_CC_Antegral to plasma membrane & $7.4 \times 10^{-2}$ \\
& & & & $3.0 \times 10^{-3}$ \\
\hline
\end{tabular}

* Differentially expressed genes were identified by comparing gene expression in the PFC of chronic alcoholics and control cases. This gene list was subjected to functional enrichment clustering using the Database for Annotation, Visualization and Integrated Discovery (DAVID; http://david.abcc.ncifcrf.gov/). Clusters with at least one significant annotation term are presented. Annotation terms are listed with associated Gene Ontology (www.geneontology.org/), InterPro (www.ebi.ac.uk/interpro/) and SwissProt/PIR/Uniprot (www.ebi.ac.uk/swissprot/, http://www.uniprot.or) categories. 
Table 5. Functional enrichment clustering of genes associated with alcohol abuse in the human nucleus accumbens (NAC)*

\begin{tabular}{|c|c|c|c|c|c|}
\hline Functional group & $n$ & Category & Annotation term & $n$ & $P$ \\
\hline \multirow[t]{8}{*}{ Enzymic activity I } & \multirow[t]{8}{*}{37} & PIR_SUPERFAMILY & Metalloproteinase inhibitor & 3 & $1.1 \times 10^{-3}$ \\
\hline & & GOTERM_MF_ALL & Enzyme inhibitor activity & 6 & $6.0 \times 10^{-3}$ \\
\hline & & GOTERM_CC_ALL & Basement membrane & 4 & $1.2 \times 10^{-2}$ \\
\hline & & GOTERM_MF_ALL & Endopeptidase inhibitor activity & 4 & $2.0 \times 10^{-2}$ \\
\hline & & GOTERM MF ALL & Protease inhibitor activity & 4 & $2.0 \times 10^{-2}$ \\
\hline & & GOTERM_MF_ALL & Enzyme regulator activity & 10 & $2.2 \times 10^{-2}$ \\
\hline & & GOTERM_CC_ALL & Proteinaceous extracellular matrix & 6 & $2.6 \times 10^{-2}$ \\
\hline & & GOTERM_CC_ALL & Extracellular matrix & 6 & $2.8 \times 10^{-2}$ \\
\hline Enzymic activity II & 22 & GOTERM_MF_ALL & Enzyme regulator activity & 10 & $2.2 \times 10^{-2}$ \\
\hline \multirow[t]{7}{*}{ Development I } & \multirow[t]{7}{*}{27} & GOTERM_BP_ALL & Cell projection organisation and biogenesis & 6 & $5.3 \times 10^{-3}$ \\
\hline & & GOTERM_BP_ALL & Anatomical structure morphogenesis & 13 & $7.4 \times 10^{-3}$ \\
\hline & & GOTERM_BP_ALL & Neuron differentiation & 6 & $8.9 \times 10^{-3}$ \\
\hline & & GOTERM_BP_ALL & Nervous system development & 10 & $1.5 \times 10^{-2}$ \\
\hline & & GOTERM_BP_ALL & Neuron development & 5 & $1.5 \times 10^{-2}$ \\
\hline & & GOTERM_BP_ALL & Regulation of neurogenesis & 3 & $1.7 \times 10^{-2}$ \\
\hline & & GOTERM_BP_ALL & Neurite morphogenesis & 4 & $3.1 \times 10^{-2}$ \\
\hline \multirow[t]{4}{*}{ Development II } & \multirow[t]{4}{*}{37} & GOTERM_BP_ALL & Anatomical structure development & 21 & $2.6 \times 10^{-3}$ \\
\hline & & GOTERM_BP_ALL & Nervous system development & 10 & $1.5 \times 10^{-2}$ \\
\hline & & GOTERM_BP_ALL & System development & 16 & $2.0 \times 10^{-2}$ \\
\hline & & GOTERM_BP_ALL & Developmental process & 24 & $3.1 \times 10^{-2}$ \\
\hline Development III & 13 & GOTERM_BP_ALL & Cell maturation & 3 & $4.0 \times 10^{-2}$ \\
\hline \multirow[t]{2}{*}{ Development IV } & 17 & GOTERM_BP_ALL & Cellular structure morphogenesis & 8 & $1.7 \times 10^{-2}$ \\
\hline & & GOTERM_BP_ALL & Cell morphogenesis & 8 & $1.6 \times 10^{-2}$ \\
\hline \multirow[t]{2}{*}{ Adhesion } & 12 & GOTERM_BP_ALL & Cell adhesion & 10 & $2.0 \times 10^{-2}$ \\
\hline & & GOTERM_BP_ALL & Cell motility & 6 & $6.2 \times 10^{-2}$ \\
\hline Transport & 30 & GOTERM_BP_ALL & Localisation & 25 & $1.3 \times 10^{-2}$ \\
\hline
\end{tabular}

* Differentially expressed genes were identified by comparing gene expression in the NAC of chronic alcoholics and control cases. This gene list was subjected to functional enrichment clustering using the Database for Annotation, Visualization and Integrated Discovery (DAVID; http://david.abcc.ncifcrf.gov/). Clusters with at least one significant annotation term are presented. Annotation terms are listed with associated Gene Ontology (www.geneontology.org/), InterPro (www.ebi.ac.uk/interpro/) and SwissProt/PIR/Uniprot (www.ebi.ac.uk/swissprot/, http://www.uniprot.or) categories.

of this brain region. Therefore enduring plasticity within the VTA may be a major molecular mechanism for the maintenance of smoking addiction and alcohol, nicotine and co-abuse have distinct impacts on glutamatergic transmission with important implications for the control of this core mesolimbic structure. Interestingly, preliminary clinical studies in subjects dependent on nicotine ${ }^{(94)}$ and alcohol $^{(95)}$ show that modulation of glutamatergic function may be a useful tool for initiation of abstinence and prevention of relapse.

These studies of core regions of the human MDS emphasise the necessity to account for smoking as a confounding variable in studies of alcoholism both with regards to dependence but also as a component of alcoholrelated brain damage. Future large-scale gene expression studies carefully delineating the effect of alcohol from that of smoking in the human MDS may further enhance our understanding of the impact of alcohol and smoking on the human brain.

\section{Protein expression studies}

Transcription profiling provides a snapshot of the mRNA spectrum of tissue under study and indicates the types of changes that may be taking place. However, mRNA is not the functional endpoint of gene expression and often mRNA abundance does not reflect protein levels ${ }^{(96,97)}$. Further, drug exposure may influence mRNA splicing or post-translational modification of a target protein, thereby altering function.

Recently, in parallel with genomic analyses, several groups have reported high-throughput studies of the proteome of MDS regions ${ }^{(98)}$. Two-dimensional gel electrophoresis, which separates proteins, firstly on isoelectric charge and then by molecular mass, can resolve over 1000 protein species. This methodology is then coupled with matrix-assisted laser desorption/ionisation time-offlight (MALDI-TOF) to confirm identity of a limited number of protein species. Currently, these analyses have been restricted to soluble proteins of mid-range molecular weight expressed at a relatively high level.

In an initial study using pooled samples from four individuals, Lewohl et al. reported changes in the levels of 183 proteins in the $\mathrm{PFC}^{(98)}$. More recently in a detailed comparative study, Matsumoto and colleagues documented changes in the proteome of the BA 9 region of the alcoholic brain ${ }^{(99)}$. Further, the proteome of the grey matter was compared with that of the underlying white matter ${ }^{(100)}$. In these studies, the influence of confounding liver disease was also monitored.

The level of several thiamine-dependent enzymes was changed in both grey and white matter. Further, almost $50 \%$ of the alcohol-sensitive proteins were metabolic enzymes, many of which are involved in energy transduction such as those involved in glycolysis and the tricarboxylic acid cycle. Disruption of these pathways, possibly emanating from a deficiency in thiamine metabolism, has several implications. Deprivation of ATP supply may lead directly to a loss of cellular viability but also disruption of the thiaminedependent enzymes of the pentose phosphate pathway may reduce the supply of reducing equivalents and therefore the cells' ability to combat oxidative stress. Many of the changes in protein expression in the alcoholic were enhanced in cases with liver disease ${ }^{(101)}$. 


\section{Gene expression studies on the human dopaminergic mesocorticolimbic system of heroin and cocaine addicts}

The impact of other drugs of abuse, in particular heroin and cocaine, on gene expression in the human NAC has been studied by Albertson et al. using the Affimetrix platform ${ }^{(102,103)}$. Seven heroin abusers were compared with matched controls and approximately 1000 genes were identified as differentially expressed ${ }^{(102)}$. Of particular interest was the down-regulation of genes encoding presynaptic proteins. These proteins are involved in aspects of neurotransmitter release, including vesicle storage, release and recycling. The results may indicate decrements in neurotransmission within the NAC of the chronic heroin abuser. In a second study, Albertson et al. compared gene expression of ten chronic cocaine abusers with matched controls ${ }^{(103)}$. Only forty-nine genes were identified to be differentially expressed in the cocaine abusers. Therefore and in contrast to the heroin study and to our studies on the NAC of chronic alcoholics, cocaine exposure might affect only a select group of genes in the human NAC. In both studies, differentially expressed genes were manually assigned to diverse functional groups. In the cocaine abusers, a number of genes were glia-specific and included genes involved in myelination. Particularly, a decrease in expression of myelin basic protein, myelin-associated oligodendrocyte basic protein and proteolipid protein was revealed. Myelin basic protein and proteolipid protein constitute about $80 \%$ of myelin in the central nervous system and a dysregulation of myelin in the cocaine abuser is consistent with white matter pathology in these addicts ${ }^{(104-106)}$. These studies highlight the specific and diverse actions of different drugs of abuse on the human NAC.

The proteome of the NAC has also been explored in cocaine abusers ${ }^{(107)}$ and in self-administering Rhesus monkeys $^{(108)}$. Consistent with the concept of drug-induced plasticity in this region of the human brain, several proteins associated with synaptic plasticity were found to have altered levels in cocaine abusers. In addition, altered metabolic flux was suggested by changes in the level of proteins involved in energy metabolism whilst other changes were suggested to reflect increased oxidative stress. In the subsequent study of the primate model, protein changes indicated a dysregulation of proteins related to cell structure, signalling and metabolism including energy generation in the mitochondria.

\section{Future studies}

Rodent models of drug-seeking behaviours and drug dependence continue to be developed. Studies of these models coupled with advances in rodent genetics will provide important information on the mechanism of action at the cellular and molecular level. It will also be important to continue with exploration of the human brain in parallel with these animal studies. Currently, a major difficulty is matching the physiological conditions of each human case. In addition to the variation in lifestyle pre-mortem, differences in post-mortem treatment of tissues are a confounding factor. However, continued improvement in public awareness, documentation and tissue treatment in the various Brain Banks worldwide should result in increased numbers of well-controlled cases for future studies.

Expression profiling experiments, by nature, generate a large amount of data. Application of analysis softwares such as DAVID (National Cancer Institute at Frederick; http:// david.abcc.ncifcrf.gov/), Pathway Assist by Stratagene (Agilent Technologies, Santa Clara, CA, USA) and others can indicate underlying biological themes. Recent advances in tools to group genes by variation of expression across individual samples have made possible the exploration of gene networks ${ }^{(109)}$. This type of analysis has been directed at diverse biological problems, for example, evolution of the human cortex ${ }^{(110)}$ and genes differentially expressed during the progression of Alzheimer's disease ${ }^{(111)}$. Similar approaches to group differentially expressed genes in the drug-affected MDS may reveal expression-related gene groups and genes central in these networks (hub genes) which may have key roles. This will give an insight into the organisation of drug-sensitive genes and possible new pharmacological targets.

Recent proteomic analyses have significantly contributed to understanding the pathophysiology of the complicated disease which is alcoholism. The data from these studies illustrate both the power and limitations of current technologies for proteomic analyses. Clearly these approaches identified important biologically relevant changes at the end point of gene expression; however, available technologies have limited ability to detect high- or low-molecular-weight proteins, and hydrophobic or insoluble proteins associated with membranes. These proteins are often important in understanding the mechanisms of central nervous system diseases. Advances in protein separation and identification have the potential to analyse expression levels of proteins, including neurotransmitter receptors and transporters that have not been examined using current techniques.

Changes in the transcriptome of the alcoholic brain may be a result of many influences. Some changes in expression may be a result of drug toxicity, some may reflect neuroadaptations associated with the development of tolerance and others may result from genetic variation. The latter may have importance in predisposition to drug dependence. Animal studies relating changes in gene expression to behaviours and to QTL maps have been invaluable in identifying potential inheritable genetic factors. Recent genome-wide association studies of alcohol $^{(112-115)}$ and nicotine dependence ${ }^{(116,117)}$ have identified several potential markers. Further meta-analyses comparing human gene expression and gene association studies will greatly aid the identification of genes and gene networks crucially involved in the predisposition to alcohol, tobacco and co-abuse in humans ${ }^{(87)}$. One recent study resulted in a systems biology network model derived by ontology-based computational genotype-phenotype association analysis of the pharmacogenetics of nicotine addiction and treatment ${ }^{(118)}$. The model encoded a disease risk model capturing the underlying biological systems and interactions with the environment. Such combined studies and analyses may reveal novel candidates to improve current treatment regimens to cease drug abuse and prevent relapse. 


\section{Acknowledgements}

The authors thank the Australian Association of Brewers Foundation and the Alcohol and Health Research Grants Scheme for financial support.

Tissues for the studies conducted by the authors were received from the Australian Brain Donor Programs NSW Tissue Resource Centre, which is supported by The University of Sydney, National Health and Medical Research Council of Australia, Neuroscience Institute of Schizophrenia and Allied Disorders, National Institute of Alcohol Abuse and Alcoholism and NSW Department of Health.

The authors contributed equally to the present review.

There are no conflicts of interest.

\section{References}

1. World Health Organization (2007) Alcohol and Injury in Emergency Departments: Summary of the Report from the WHO Collaborative Study on Alcohol and Injuries. Geneva: WHO. http://www.who.int/substance_abuse/publications/ alcohol_injury_summary.pdf

2. World Health Organization (2004) Global Status Report on Alcohol 2004. Geneva: WHO. http://www.who.int/substance_ abuse/publications/global_status_report_2004_overview.pdf

3. Robins L \& Regier D (1991) Psychiatric Disorders in America: The Epidemiologic Catchment Area Study. New York: The Free Press.

4. Bates ME, Bowden SC \& Barry D (2002) Neurocognitive impairment associated with alcohol use disorders: implications for treatment. Exp Clin Psychopharmacol 10, 193-212.

5. Glenn SW, Errico AL, Parsons OA, et al. (1993) The role of antisocial, affective, and childhood behavioral characteristics in alcoholics' neuropsychological performance. Alcohol Clin Exp Res 17, 162-169.

6. Pishkin V, Lovallo WR \& Bourne LE Jr (1985) Chronic alcoholism in males: cognitive deficit as a function of age of onset, age, and duration. Alcohol Clin Exp Res 9, 400-406.

7. Levinson P, Gernstein D \& Maloff DE (1983) Commonalities of Substance Abuse and Habitual Behavior. Lexington, MA: Lexington Books.

8. Blume A, Schmaling K \& Marlatt G (2000) Revisiting the self-medication hypothesis from a behavioral perspective. Cogn Behav Pract 7, 379-384.

9. Burling TA \& Ziff DC (1988) Tobacco smoking: a comparison between alcohol and drug abuse inpatients. Addict Behav 13, 185-190.

10. DiFranza JR \& Guerrera MP (1990) Alcoholism and smoking. J Stud Alcohol 51, 130-135.

11. Batel P, Pessione F, Maitre C, et al. (1995) Relationship between alcohol and tobacco dependencies among alcoholics who smoke. Addiction 90, 977-980.

12. Larsson A \& Engel JA (2004) Neurochemical and behavioral studies on ethanol and nicotine interactions. Neurosci Biobehav Rev 27, 713-720.

13. Di Chiara G \& Imperato A (1988) Drugs abused by humans preferentially increase synaptic dopamine concentrations in the mesolimbic system of freely moving rats. Proc Natl Acad Sci U S A 85, 5274-5278.

14. Di Chiara G \& Bassareo V (2007) Reward system and addiction: what dopamine does and doesn't do. Curr Opin Pharmacol 7, 69-76.
15. Wilson DI \& Bowman EM (2006) Neurons in dopaminerich areas of the rat medial midbrain predominantly encode the outcome-related rather than behavioural switching properties of conditioned stimuli. Eur $J$ Neurosci 23, 205-218.

16. Borlikova GG, Le Merrer J \& Stephens DN (2006) Previous experience of ethanol withdrawal increases withdrawalinduced c-fos expression in limbic areas, but not withdrawal-induced anxiety and prevents withdrawal-induced elevations in plasma corticosterone. Psychopharmacology (Berl) 185, 188-200.

17. Dayas CV, Liu X, Simms JA, et al. (2006) Distinct patterns of neural activation associated with ethanol seeking: effects of naltrexone. Biol Psychiatry 61, 979-989.

18. De Biasi M \& Salas R (2008) Influence of neuronal nicotinic receptors over nicotine addiction and withdrawal. Exp Biol Med (Maywood) 233, 917-929.

19. Ryan RE \& Loiacono RE (2001) Nicotine regulates $\alpha 7$ nicotinic receptor subunit mRNA: implications for nicotine dependence. Neuroreport 12, 569-572.

20. Vengeliene V, Bilbao A, Molander A, et al. (2008) Neuropharmacology of alcohol addiction. Br J Pharmacol 154, 299-315.

21. Nisell M, Nomikos GG \& Svensson TH (1994) Systemic nicotine-induced dopamine release in the rat nucleus accumbens is regulated by nicotinic receptors in the ventral tegmental area. Synapse 16, 36-44.

22. Wooltorton JR, Pidoplichko VI, Broide RS, et al. (2003) Differential desensitization and distribution of nicotinic acetylcholine receptor subtypes in midbrain dopamine areas. J Neurosci 23, 3176-3185.

23. Schilstrom B, Fagerquist MV, Zhang X, et al. (2000) Putative role of presynaptic $\alpha 7 *$ nicotinic receptors in nicotine stimulated increases of extracellular levels of glutamate and aspartate in the ventral tegmental area. Synapse 38, 375-383.

24. Bierut LJ, Schuckit MA, Hesselbrock V, et al. (2000) Cooccurring risk factors for alcohol dependence and habitual smoking. Alcohol Res Health 24, 233-241.

25. Bevilacqua L \& Goldman D (2009) Genes and addictions. Clin Pharmacol Ther 85, 359-361.

26. Crabbe JC (2008) Review. Neurogenetic studies of alcohol addiction. Philos Trans $R$ Soc Lond B Biol Sci 363, 3201-3211.

27. Crabbe JC, Phillips TJ, Kosobud A, et al. (1990) Estimation of genetic correlation: interpretation of experiments using selectively bred and inbred animals. Alcohol Clin Exp Res 14, 141-151.

28. Gora-Maslak G, McClearn GE, Crabbe JC, et al. (1991) Use of recombinant inbred strains to identify quantitative trait loci in psychopharmacology. Psychopharmacology (Berl) 104, 413-424.

29. Bhave SV, Hoffman PL, Lassen N, et al. (2006) Gene array profiles of alcohol and aldehyde metabolizing enzymes in brains of C57BL/6 and DBA/2 mice. Alcohol Clin Exp Res 30, 1659-1669.

30. Tabakoff B, Bhave SV \& Hoffman PL (2003) Selective breeding, quantitative trait locus analysis, and gene arrays identify candidate genes for complex drug-related behaviors. J Neurosci 23, 4491-4498.

31. Carr LG, Kimpel MW, Liang T, et al. (2007) Identification of candidate genes for alcohol preference by expression profiling of congenic rat strains. Alcohol Clin Exp Res 31, 1089-1098.

32. Newton PM \& Messing RO (2006) Intracellular signaling pathways that regulate behavioral responses to ethanol. Pharmacol Ther 109, 227-237. 
33. Mulligan MK, Ponomarev I, Hitzemann RJ, et al. (2006) Toward understanding the genetics of alcohol drinking through transcriptome meta-analysis. Proc Natl Acad Sci U S A 103, 6368-6373.

34. Bennett B \& Johnson TE (1998) Development of congenics for hypnotic sensitivity to ethanol by QTL-marker-assisted counter selection. Mamm Genome 9, 969-974.

35. Acquaah-Mensah GK, Misra V \& Biswal S (2006) Ethanol sensitivity: a central role for CREB transcription regulation in the cerebellum. BMC Genomics 7, 308.

36. Sommer W, Hyytia P \& Kiianmaa K (2006) The alcoholpreferring AA and alcohol-avoiding ANA rats: neurobiology of the regulation of alcohol drinking. Addict Biol 11, 289-309.

37. Arlinde C, Sommer W, Bjork K, et al. (2004) A cluster of differentially expressed signal transduction genes identified by microarray analysis in a rat genetic model of alcoholism. Pharmacogenomics J 4, 208-218.

38. Letwin NE, Kafkafi N, Benjamini Y, et al. (2006) Combined application of behavior genetics and microarray analysis to identify regional expression themes and gene-behavior associations. J Neurosci 26, 5277-5287.

39. Kerns RT, Ravindranathan A, Hassan S, et al. (2005) Ethanol-responsive brain region expression networks: implications for behavioral responses to acute ethanol in DBA/2J versus C57BL/6J mice. J Neurosci 25, 2255-2266.

40. Singh SM, Treadwell J, Kleiber ML, et al. (2007) Analysis of behavior using genetical genomics in mice as a model: from alcohol preferences to gene expression differences. Genome 50, 877-897.

41. Hu W, Saba L, Kechris K, et al. (2008) Genomic insights into acute alcohol tolerance. J Pharmacol Exp Ther 326, 792-800.

42. Rulten SL, Ripley TL, Hunt CL, et al. (2006) Sp1 and NFкB pathways are regulated in brain in response to acute and chronic ethanol. Genes Brain Behav 5, 257-273.

43. Saito M, Smiley J, Toth R, et al. (2002) Microarray analysis of gene expression in rat hippocampus after chronic ethanol treatment. Neurochem Res 27, 1221-1229.

44. Rimondini R, Arlinde C, Sommer W, et al. (2002) Longlasting increase in voluntary ethanol consumption and transcriptional regulation in rat brain after intermittent exposure to alcohol. FASEB J 16, 27-35.

45. Gessa GL, Serra S, Vacca G, et al. (2005) Suppressing effect of the cannabinoid CB1 receptor antagonist, SR147778, on alcohol intake and motivational properties of alcohol in alcohol-preferring sP rats. Alcohol Alcohol 40, 46-53.

46. Repunte-Canonigo V, Lutjens R, van der Stap LD, et al. (2007) Increased expression of protein kinase A inhibitor $\alpha$ $(\mathrm{PKI}-\alpha)$ and decreased PKA-regulated genes in chronic intermittent alcohol exposure. Brain Res 1138, 48-56.

47. Saito M, Szakall I, Toth R, et al. (2004) Mouse striatal transcriptome analysis: effects of oral self-administration of alcohol. Alcohol 32, 223-241.

48. Rodd ZA, Kimpel MW, Edenberg HJ, et al. (2008) Differential gene expression in the nucleus accumbens with ethanol self-administration in inbred alcohol-preferring rats. Pharmacol Biochem Behav 89, 481-498.

49. Hashimoto JG \& Wiren KM (2008) Neurotoxic consequences of chronic alcohol withdrawal: expression profiling reveals importance of gender over withdrawal severity. Neuropsychopharmacology 33, 1084-1096.

50. Chen X, Che Y, Zhang L, et al. (2007) RhoA, encoding a Rho GTPase, is associated with smoking initiation. Genes Brain Behav 6, 689-697.

51. Vadasz C, Saito M, O'Brien D, et al. (2007) Ventral tegmental transcriptome response to intermittent nicotine treatment and withdrawal in BALB/cJ, C57BL/6ByJ, and quasi-congenic RQI mice. Neurochem Res 32, 457-480.

52. Konu O, Kane JK, Barrett T, et al. (2001) Region-specific transcriptional response to chronic nicotine in rat brain. Brain Res 909, 194-203.

53. Li MD, Kane JK, Wang J, et al. (2004) Time-dependent changes in transcriptional profiles within five rat brain regions in response to nicotine treatment. Brain Res Mol Brain Res 132, 168-180.

54. Kane JK, Konu O, Ma JZ, et al. (2004) Nicotine coregulates multiple pathways involved in protein modification/degradation in rat brain. Brain Res Mol Brain Res 132, 181-191.

55. Belluardo N, Olsson PA, Mudo G, et al. (2005) Transcription factor gene expression profiling after acute intermittent nicotine treatment in the rat cerebral cortex. Neuroscience 133, 787-796.

56. Wang J, Gutala R, Hwang YY, et al. (2008) Strain- and region-specific gene expression profiles in mouse brain in response to chronic nicotine treatment. Genes Brain Behav 7, 78-87.

57. Robinson SF, Marks MJ \& Collins AC (1996) Inbred mouse strains vary in oral self-selection of nicotine. Psychopharmacology (Berl) 124, 332-339.

58. Marks MJ, Burch JB \& Collins AC (1983) Genetics of nicotine response in four inbred strains of mice. J Pharmacol Exp Ther 226, 291-302.

59. Marks MJ, Campbell SM, Romm E, et al. (1991) Genotype influences the development of tolerance to nicotine in the mouse. J Pharmacol Exp Ther 259, 392-402.

60. Ulrich J, Johannson-Locher G, Seiler WO, et al. (1997) Does smoking protect from Alzheimer's disease? Alzheimer-type changes in 301 unselected brains from patients with known smoking history. Acta Neuropathol 94, 450-454.

61. Shimohama S \& Kihara T (2001) Nicotinic receptormediated protection against $\beta$-amyloid neurotoxicity. Biol Psychiatry 49, 233-239.

62. Gutala R, Wang J, Hwang YY, et al. (2006) Nicotine modulates expression of amyloid precursor protein and amyloid precursor-like protein 2 in mouse brain and in SH-SY5Y neuroblastoma cells. Brain Res 1093, 12-19.

63. Flatscher-Bader T, Zuvela N, Landis N, et al. (2008) Smoking and alcoholism target genes associated with plasticity and glutamate transmission in the human ventral tegmental area. Hum Mol Genet 17, 38-51.

64. Flatscher-Bader T, van der Brug M, Hwang JW, et al. (2005) Alcohol-responsive genes in the frontal cortex and nucleus accumbens of human alcoholics. J Neurochem 93 , 359-370.

65. Mayfield RD, Lewohl JM, Dodd PR, et al. (2002) Patterns of gene expression are altered in the frontal and motor cortices of human alcoholics. $J$ Neurochem 81, 802-813.

66. Lewohl JM, Wang L, Miles MF, et al. (2000) Gene expression in human alcoholism: microarray analysis of frontal cortex. Alcohol Clin Exp Res 24, 1873-1882.

67. Liu J, Lewohl JM, Dodd PR, et al. (2004) Gene expression profiling of individual cases reveals consistent transcriptional changes in alcoholic human brain. J Neurochem 90, 1050-1058.

68. Sokolov BP, Jiang L, Trivedi NS, et al. (2003) Transcription profiling reveals mitochondrial, ubiquitin and signaling systems abnormalities in postmortem brains from subjects with a history of alcohol abuse or dependence. J Neurosci Res 72, 756-767.

69. Iwamoto K, Bundo M, Yamamoto M, et al. (2004) Decreased expression of NEFH and PCP4/PEP19 in the prefrontal cortex of alcoholics. Neurosci Res 49, 379-385. 
70. Harper C \& Kril J (1985) Brain atrophy in chronic alcoholic patients: a quantitative pathological study. J Neurol Neurosurg Psychiatry 48, 211-217.

71. Kril JJ, Halliday GM, Svoboda MD, et al. (1997) The cerebral cortex is damaged in chronic alcoholics. Neuroscience 79, 983-998.

72. Kril JJ \& Harper CG (1989) Neuronal counts from four cortical regions of alcoholic brains. Acta Neuropathol (Berl) 79, 200-204.

73. Hoffman PL \& Tabakoff B (1994) The role of the NMDA receptor in ethanol withdrawal. EXS 71, 61-70.

74. Freund G \& Anderson KJ (1996) Glutamate receptors in the frontal cortex of alcoholics. Alcohol Clin Exp Res 20, $1165-1172$.

75. Rossetti ZL \& Carboni S (1995) Ethanol withdrawal is associated with increased extracellular glutamate in the rat striatum. Eur J Pharmacol 283, 177-183.

76. Flatscher-Bader T \& Wilce PA (2006) Chronic smoking and alcoholism change expression of selective genes in the human prefrontal cortex. Alcohol Clin Exp Res 30, 908-915.

77. Flatscher-Bader T \& Wilce PA (2008) Impact of alcohol abuse on protein expression of midkine and excitatory amino acid transporter 1 in the human prefrontal cortex. Alcohol Clin Exp Res 32, 1849-1858.

78. Calabrese V, Renis M, Calderone A, et al. (1998) Stress proteins and SH-groups in oxidant-induced cellular injury after chronic ethanol administration in rat. Free Radic Biol Med 24, 1159-1167.

79. Renis M, Calabrese V, Russo A, Calderone A, et al. (1996) Nuclear DNA strand breaks during ethanol-induced oxidative stress in rat brain. FEBS Lett 390, 153-156.

80. Flatscher-Bader T, van der Brug MP, Landis N, et al. (2006) Comparative gene expression in brain regions of human alcoholics. Genes Brain Behav 5, Suppl. 1, 78-84.

81. Dennis G Jr, Sherman BT, Hosack DA, et al. (2003) DAVID: Database for Annotation, Visualization, and Integrated Discovery. Genome Biol 4, P3.

82. Hosack DA, Dennis G Jr, Sherman BT, et al. (2003) Identifying biological themes within lists of genes with EASE. Genome Biol 4, R70.

83. Huang da W, Sherman BT \& Lempicki RA (2009) Systematic and integrative analysis of large gene lists using DAVID bioinformatics resources. Nat Protoc 4, 44-57.

84. Robinson TE \& Kolb B (2004) Structural plasticity associated with exposure to drugs of abuse. Neuropharmacology 47, Suppl. 1, 33-46.

85. Rodd ZA, Bertsch BA, Strother WN, et al. (2007) Candidate genes, pathways and mechanisms for alcoholism: an expanded convergent functional genomics approach. Pharmacogenomics J 7, 222-256.

86. Drobes DJ, Beylotte F, Scott M, et al. (2000) Crossreactivity to alcohol and smoking cues. Alcohol Clin Exp Res 24, 147a.

87. Li MD \& Burmeister M (2009) New insights into the genetics of addiction. Nat Rev Genet 10, 225-231.

88. Wada M, Kamata M, Aizu Y, et al. (2002) Alteration of midkine expression in the ischemic brain of humans. $J$ Neurol Sci 200, 67-73.

89. Wetzel M, Rosenberg GA \& Cunningham LA (2003) Tissue inhibitor of metalloproteinases- 3 and matrix metalloproteinase-3 regulate neuronal sensitivity to doxorubicin-induced apoptosis. Eur J Neurosci 18, 1050-1060.

90. Thomas EA, Dean B, Pavey G, et al. (2001) Increased CNS levels of apolipoprotein D in schizophrenic and bipolar subjects: implications for the pathophysiology of psychiatric disorders. Proc Natl Acad Sci U S A 98, 4066-4071.

91. Glass JM, Adams KM, Nigg JT, et al. (2006) Smoking is associated with neurocognitive deficits in alcoholism. Drug Alcohol Depend 82, 119-126.

92. Durazzo TC, Cardenas VA, Studholme C, et al. (2007) Nontreatment-seeking heavy drinkers: effects of chronic cigarette smoking on brain structure. Drug Alcohol Depend 87, 76-82.

93. Mansvelder HD \& McGehee DS (2000) Long-term potentiation of excitatory inputs to brain reward areas by nicotine. Neuron 27, 349-357.

94. Harris DS \& Anthenelli RM (2005) Expanding treatment of tobacco dependence. Curr Psychiatry Rep 7, 344-351.

95. Penberthy JK, Ait-Daoud N, Breton M, et al. (2007) Evaluating readiness and treatment seeking effects in a pharmacotherapy trial for alcohol dependence. Alcohol Clin Exp Res 31, 1538-1544.

96. Gygi SP, Rochon Y, Franza BR, et al. (1999) Correlation between protein and mRNA abundance in yeast. Mol Cell Biol 19, 1720-1730.

97. Anderson L \& Seilhamer J (1997) A comparison of selected mRNA and protein abundances in human liver. Electrophoresis 18, 533-537.

98. Lewohl JM, Van Dyk DD, Craft GE, et al. (2004) The application of proteomics to the human alcoholic brain. Ann N Y Acad Sci 1025, 14-26.

99. Alexander-Kaufman K, James G, Sheedy D, et al. (2006) Differential protein expression in the prefrontal white matter of human alcoholics: a proteomics study. Mol Psychiatry 11, 56-65.

100. Alexander-Kaufman K, Cordwell S, Harper C, et al. (2007) A proteome analysis of the dorsolateral prefrontal cortex in human alcoholic patients. Proteomics Clin Appl 1, 62-72.

101. Matsumoto I, Alexander-Kaufman K, Iwazaki T, et al. (2007) CNS proteomes in alcohol and drug abuse and dependence. Expert Rev Proteomics 4, 539-552.

102. Albertson DN, Schmidt CJ, Kapatos G, et al. (2006) Distinctive profiles of gene expression in the human nucleus accumbens associated with cocaine and heroin abuse. Neuropsychopharmacology 31, 2304-2312.

103. Albertson DN, Pruetz B, Schmidt CJ, et al. (2004) Gene expression profile of the nucleus accumbens of human cocaine abusers: evidence for dysregulation of myelin. J Neurochem 88, 1211-1219.

104. Bartzokis G, Beckson M, Lu PH, et al. (2002) Brain maturation may be arrested in chronic cocaine addicts. Biol Psychiatry 51, 605-611.

105. Lim KO, Choi SJ, Pomara N, et al. (2002) Reduced frontal white matter integrity in cocaine dependence: a controlled diffusion tensor imaging study. Biol Psychiatry 51, 890-895.

106. Chang L, Ernst T, Strickland T, et al. (1999) Gender effects on persistent cerebral metabolite changes in the frontal lobes of abstinent cocaine users. Am J Psychiatry 156, $716-722$.

107. Tannu N, Mash DC \& Hemby SE (2007) Cytosolic proteomic alterations in the nucleus accumbens of cocaine overdose victims. Mol Psychiatry 12, 55-73.

108. Tannu NS, Howell LL \& Hemby SE (2008) Integrative proteomic analysis of the nucleus accumbens in rhesus monkeys following cocaine self-administration. Mol Psychiatry 27, 27.

109. Horvath S, Zhang B, Carlson M, et al. (2006) Analysis of oncogenic signaling networks in glioblastoma identifies ASPM as a molecular target. Proc Natl Acad Sci U S A 103, $17402-17407$. 
110. Oldham MC, Horvath S \& Geschwind DH (2006) Conservation and evolution of gene coexpression networks in human and chimpanzee brains. Proc Natl Acad Sci U S A 103, 17973-17978.

111. Miller JA, Oldham MC \& Geschwind DH (2008) A systems level analysis of transcriptional changes in Alzheimer's disease and normal aging. J Neurosci 28, 1410-1420.

112. Rice JP \& Saccone SF (2005) Alcoholism and related traits: a summary of Group 13 contributions. Genet Epidemiol 29, Suppl. 1, S96-S102.

113. Li X, Rao SQ, Zhang W, et al. (2006) Decision forest analysis of large-scale sib-pair identical-by-decent profiles for locating the underlying disease genes for alcoholism in human. Beijing Da Xие Xие Bao 38, 71-73.
114. Edenberg HJ \& Foroud T (2006) The genetics of alcoholism: identifying specific genes through family studies. Addict Biol 11, 386-396.

115. Ducci F \& Goldman D (2008) Genetic approaches to addiction: genes and alcohol. Addiction 103, 1414-1428.

116. Uhl GR, Liu QR, Drgon T, et al. (2008) Molecular genetics of successful smoking cessation: convergent genome-wide association study results. Arch Gen Psychiatry 65, 683-693.

117. Bierut LJ, Madden PA, Breslau N, et al. (2007) Novel genes identified in a high-density genome wide association study for nicotine dependence. Hum Mol Genet 16, 24-35.

118. Thomas PD, Mi H, Swan GE, et al. (2009) A systems biology network model for genetic association studies of nicotine addiction and treatment. Pharmacogenet Genomics 19, 538-551. 